\title{
La radiologia medica: looking to future challenges in full awareness of a prestigious past
}

\section{La radiologia medica: una sfida per il futuro nella consapevolezza di un prestigioso passato}

\section{Andrea Giovagnoni}

General and Pediatric Radiology, University Politecnica delle Marche, Ancona, Italy

Published online: 28 November 2012

(C) Springer-Verlag 2012

Dear Colleagues,

A few words to present the December issue of La radiologia medica as the new Editor-in-Chief, after the long and prestigious term served by Prof. Pozzi Mucelli, who left the position after more than ten years.

My predecessor succeeded in raising the journal to a dignity and scientific standing which has placed it among the top-ranking radiology journals in Europe and worldwide, and for this unrepeatable achievement I thank him on behalf of the entire Italian radiological community as well.

In this early phase, I am working both on revamping the Editorial Board by appointing two Deputy Editors, in bearing with the Society's rules, and on reorganising the Advisory Editorial Board and the list of Peer Referees.

The challenges awaiting the new working group are many and complex. The objectives are not only to maintain the current impact factor through a careful and strict selection of manuscripts, but also to progressively extend the journal's international scope, consistent with the levels already reached by many Italian radiologists.

In agreement with what was discussed by the SIRM Executive Board, we will soon present the new editorial project whereby two parallel journals will be issued as of the year 2014. One will be in English and only available on-line to ensure international visibility and scientific quality, with special attention being paid to increasing the Impact Factor. The other, in Italian, will be printed and distributed to all SIRM members in the usual manner.

In particular, the Italian journal will contain a translation of the English on-line version, supplemented by a series of educational articles, reviews, case reports, consensus papers and reports, with the aim of providing members with a prac-
Cari Colleghi,

Mi accingo a presentare il numero di dicembre de La radiologia medica come nuovo Direttore Editoriale, dopo il lungo e prestigioso periodo di Direzione del Prof. Pozzi Mucelli, che ha lasciato l'incarico dopo più di dieci anni.

Chi mi ha preceduto, ha saputo elevare la Rivista ad una dignità e valore scientifico che la pone ai primi posti, non solo in Europa, fra le riviste del settore e per questa opera irripetibile lo ringrazio a nome mio e di tutta la Radiologia italiana.

In questa prima fase sto lavorando sia al rinnovo dell'Editorial Board, in linea con il regolamento Societario, con la nomina dei due Vice-Direttori, che alla ristrutturazione del Comitato Consultivo Editoriale e della lista dei Peer Referee.

Le sfide che attendono il nuovo gruppo di lavoro saranno molteplici e complesse, non solo volte a mantenere i livelli bibliometrici raggiunti attraverso una rigida e accurata selezione degli articoli, ma anche a lavorare affinché la Rivista assuma sempre di più un "respiro" internazionale, coerente con il livello già raggiunto da molti radiologi italiani.

In accordo con quanto discusso in seno al Consiglio Direttivo SIRM, sarà presto presentato il nuovo progetto editoriale che prevederà, a partire dal 2014, la costituzione di due riviste parallele, una in inglese solo su web, che assicuri la visibilità internazionale degli Autori e la valenza scientifica con particolare riguardo all'incremento del "Impact Factor", e una in Italiano, che verrà stampata e distribuita con le stesse modalità attuali a tutti i Soci SIRM.

In particolare la versione italiana conterrà la versione inglese on-line tradotta, corredata e implementata da una serie di articoli educazionali, review, case report, documenti e articoli di consensus così da essere un pratico strumento di 
tical and easy-to-consult resource for work and professional development.

Next year SIRM will be 100 years old: a major Society with a long history full of prestigious achievements which has always placed its members with their needs and cultural and professional growth at the forefront, with a view to safeguarding radiology and the patient's best interests. From this perspective, La radiologia medica is and will increasingly be a modern and effective link connecting Society members with the scientific community.

My personal commitment - and that of my collaborators - towards attaining these goals will be total, and strengthened by an intention to ensure that our activities are widely and constantly publicised.

My heartfelt thanks to all the authors and readers of $L a$ radiologia medica who have believed in the journal until now and who intend to support its activities for many years to come. lavoro e di aggiornamento professionale facilmente consultabile a disposizione del Socio.

La SIRM il prossimo anno compirà 100 anni; una Società grande, una storia lunga e ricca di prestigiosi traguardi che ha messo sempre in primo piano il Socio, le sue esigenze, la sua crescita culturale e professionale per la salvaguardia della disciplina e per il bene del paziente e in questa ottica La radiologia medica è, e sarà sempre di più, uno strumento moderno ed efficace di connessione fra Socio e Comunità Scientifica.

Il mio impegno personale e quello dei Collaboratori sarà massimo per il raggiungimento degli obiettivi prefissati, rafforzato dalla volontà di assicurare un'ampia e costante divulgazione dell' attività svolta.

Il mio ringraziamento va a tutti gli Autori e i Lettori de $\mathrm{La}$ radiologia medica che fino a qui hanno creduto nella rivista e che vorranno sostenerne la sua attività per lunghi anni ancora. 